УДК [82(47+57).09:305-055.2]„196/197”

\title{
RUSSIAN-SOVIET LITERATURE OF THE 1960S AND 1970S: MOTHERHOOD IN DISGUISE, OR A MALE ANTI-FEMINIST RHETHORIC FOR WHAT IT'S WORTH
}

\author{
Ольга Табачнікова \\ otabachnikova@uclan.ac.uk
}

Доктор філософії (кандидат филологічних наук), доцент, завідуюча кафедрою

Кафедра російської мови, літератури і культури

Університет Центрального Ланкашира

Вул. Аделфі, PR1 2HE, м. Престон, Великобританія

Анотація. Здійснюється аналіз радянської літератури періодів відлиги і застою (1960 - 1970-ті роки) з гендерної точки зору, піддається переоцінці існуюча (принаймні на Заході) парадигма сприйняття цієї літератури як анти-феміністської. Спочатку розглядається літературне зображення материнства особливо у випадку працюючих матерів, - а потім феміністське прочитання цієї літератури в більш загальному ключі. Пропонується альтернативна інтерпретація літературних творів даного періоду (особливо написаних чоловіками), що піддає сумніву їх анти-феміністську спрямованість. Оголюючи приховані комплекси авторів-чоловіків, що стоять за їх часто непримиренною риторикою, доводиться, що домінантою моделлю в цій літературі насправді служить не патріархальна модель, а саме модель материнства, що розуміється в широкому сенсі. Зроблено висновок, що цю літературу слід читати як свого роду шифр, оскільки зовні анти-феміністська, вона не така за своєю суттю.

Ключові слова: гендер, фемінізм, анти-феміністська риторика, радянська література, материнство, патріархальний/матріархальний.

The story of mankind told through books is essentially a story of corruption and thus the story of an existential trial. At the beginning there is the Fall where the serpent first corrupts the woman, and only then the woman corrupts the man. This tells us two things: first that it is the woman who leads the man on, that is to say, who is in control of him;

(C) Табачнікова 0., 2017 
and secondly, that it is the woman with whom the primary guilt lies. Moreover it turns out that it is the woman, not the man who can bear children. Thus human history from a gender perspective can be viewed as the revenge of a man's wounded and insulted ego striving to overthrow woman's intrinsic dominance, to escape her control and to punish her for his own fall, thus shifting responsibility.

What can be derived from this symbolic interpretation to serve our purposes is the basic assumption that at the root of any biased and aggressive attitude there lies a certain inferiority complex.

As Julia Voznesenskaia wrote from prison to a male friend referring to men in general: "your discoveries, your much-vaunted progress (with its prisons, camps, atom bombs, and heaven knows what other male entertainments) - all this comes from a hidden inferiority complex - you just can't give birth to a child, that's what it is!" $[9$, p. 178].

This particular approach proves strangely relevant and productive in our context when discussing the portrayal of women in the Soviet Russian literature of the 1960s and 1970s. And, rather paradoxically, it allows us in some sense to rehabilitate that literature in terms of at least some aspects of the biased gender representation. What exactly I mean by this will become clear shortly.

In the Soviet Union with its proclaimed equality of men and women and the declaration that the 'woman question' had been resolved back in the 1930s, the theme of women's existence, especially involving family and motherhood, with its routines and challenges, was mostly misrepresented in official literature. Rosalind Marsh emphasises that the idealisation of the mother figure was widespread in masculine twentieth century Russian literature and points out that

such a reverential attitude to motherhood in Russian culture, which reflects profound needs on the part of male writers and Russian men in general, could be oppressive and damaging to actual Russian women, since the real experience of motherhood has hardly been examined, and the female perspective on maternity has been consistently ignored [14, p. 19-20].

The cult of Stalin's personality obviously did not assist a true portrayal of the quite terrifying Soviet realities. The beginning of the Thaw saw changes both in life and in literature. The 1960s and 1970s 
became years of a rapid improvement in living conditions and women's mass employment, when women started to earn proper salaries which were essentially, even if often less in actual terms, still within the same range as those of their male partners. Thus women effectively (rather than on paper) acquired basic equality with men. Moreover, they now found themselves in the situation of the double burden, where their responsibilities at work were complemented by their domestic duties, which included, as before, housework and child care, and all this in the frustrating conditions of Soviet everyday hardship. But by having to cope with so much and by becoming the central pillars of their families' everyday existence, they also acquired real authority within the family, because it was they who made this existence possible.

However, the portrayal of this situation in literature was ambivalent, largely due to the surviving cultural canon dominated by men. Essentially the change in gender stereotypes in cultural terms was not catching up with the rapid female emancipation. Barbara Heldt's subsequent statement can also be accurately applied to the period in question:

in the Soviet Union the most acclaimed writers of prose fiction were still male; they wrote within a realistic framework and their heroines generally reflected the projections of male consciousness we had seen in nineteenth-century works which idealised women, when not either pitying or castigating them for materialism [11, p. 149].

Thus, although the time itself seemed ripe in social terms for the emergence of such a work as Baranskaia's $A$ Week Like Any Other (1969), this work did not initiate a tradition and such a radical literary experiment was essentially discontinued up until the 1980s. As Catriona Kelly observed "there are few Soviet fictional texts that confront women's material deprivation and social exploitation as directly as A Week Like Any Other" [12, p. 400]. There were various reasons for this. First, because of the male dominance in Russian literature, everyday humdrum existence, which first and foremost consisted of the preoccupations of the mother of a family, was outside the authors' concerns. "Byt" (this day to day routine) in general was not historically part of Russian literary discourse. 
The female predicament was traditionally closely tied to domestic chores which resisted being elevated to the object of art, especially during socialist realism with its varnishing tendencies on the one hand and horrific reality on the other. Hypocritical socialist art was above such "paltry matters", and thus this topic received very little coverage, especially due to the danger exuded by the subversive nature of any truthful descriptions of Soviet "byt". It was not until the appearance of Petrushevskaia that family life received its due in a rather Dostoevskian way, when it was given both a fully adequate and masterful portrayal of mundane brutality, single motherhood, dysfunctional relations both within and between generations, drunkenness, violence, and so on. In the 1960s and 1970s these types of depictions were present only in the underground or semi-underground tradition. Thus Vladimir Vysotsky's "tut za den' tak nakuvyrkaesh'sa, pridyosh' domoj - tam ty sidish!" [2, p. 360] (I get so tumbled up during the day, only to come home and to find you there!) carries, in the genre of parody, the chilling horror of the true life of a dysfunctional family from a low social stratum, its lost selfrespect and gender prejudices. Sergei Dovlatov's then unpublishable works contained statements about the existing reality of sanctimony pertaining to family and gender amongst the intelligentsia or nearintelligentsia circles:

Some [women] were unfaithful to their husbands. Some were rudely bossed about by them. Many had to put up with infidelity themselves. But still - they were married. The very presence of a husband gave them value in the eyes of people around them. A husband was absolutely essential. It was necessary to have one, if only as an object of hatred [13, p. 254].

It is also in Dovlatov's text that a story of a suicide by a single mother working as the secretary for a journal's editorial board is mentioned [3, p. 317-319]. However, if in Dovlatov's work this story of the doom of single motherhood surrounded by the total indifference of people around her is rather peripheral, it occupies a central place in Vasil' Bykov's novella "На сцяжыне жыцця" ["On the trail of life"] (1958; later appearing as a screen adaptation under the title "Fruzia"), which depicts a young woman working as a cleaner at some establishment and getting seduced by a married long-distance driver. She gets pregnant by him and becomes a single mother, but the story focuses 
as much, if not more, on the horrifying sanctimony and invincible despotism of Soviet reality closing in on a defenseless creature as it does on a particular existential experience that ends in misery.

Other texts generally add up to the message of women's divine endurance, stoic behaviour and moral superiority to men. These examples also illustrate cultural continuity in the gender context. However, in such depictions the previous gender stereotypes, as they evolved in Soviet Russia towards the second half of the twentieth century, remain essentially unshaken by the rapidly changing times. One could speak of female writers' potential ability to reflect women's concerns in literature, but those were scarce, limited by the same ideological constraints and, even more importantly, conforming to the both stereotypes of the preoccupations of art and of gender roles which, although now allowing a woman to occupy her place at work beside a man, still prescribed her location in the kitchen, in motherhood and in love relationships with men, while men's function was always of broader application, concerning general creativity and abstract thought.

In this sense Pasternak's image of a woman delivered, significantly, by a female character in his Doctor Zhivago largely encapsulates the common stance: "you were given wings to fly above the clouds, but I'm a woman, mine are given me to stay close to the ground and to shelter my young" [5, p. 586]. This description is more capacious and multi-faceted than it seems because it validates, while simultaneously ennobling and thus justifying it, a woman's essentially self-sacrificial function designed to enhance and facilitate man's existence. Her place is perceived as that of a mother and a wife, angelic and morally superior in her selflessness, and yet close to the ground, thus hinting at her down-to-earth concrete and practical nature. At best she is a man's muse, at worst - a reproductive machine devoted to caring for her offspring and for her man.

Even in a family that is perceived as happy and harmonious, the gender roles were strictly delineated. Thus in Viktor Dragunsky's "Deniska's Stories" (1959) which portrays family life as seen through the eyes of a child, the father is depicted as strong, dominant and straightforward, while the mother comes across as beautiful, emotionally flexible and adaptable. The mother, who has a full time job, is still the only one who does the housework. The father is completely useless in 
the kitchen, cannot even boil a chicken, and does not participate in the dish-washing process, much to the mother's exasperation. Yet, this is a distinctly happy family with mutual love between the spouses.

The highly non-uniform role distribution which simply mirrored the existing gender-stereotypes of real life was impressed upon literature and defined the cliché of specifically "female" literature. Thus, Yuri Nagibin when introducing a new female name - that of Nadezhda Kozhevnikova - to the readers of Novyi Mir, unwittingly characterised her novella as: "purely female in content, but not, nevertheless, a ladylike needlework in the way of performance" [4, p. 15]. This said, he was a writer whose images of women were by and large, if not idealised, then conceived with great care and even tenderness. At least he acknowledged the existence of some superior trend (implicitly equaling men's writing) in women's literature. Many of his male colleagues were (and still continue to be) less generous. If they could give ground to women in some matters, like, say, morality, then male superior intelligence and creative abilities were the last piece of land which they were not prepared to give up under any circumstances. Thus Nikolai Zabolotsky famously annoyed Akhmatova by claiming that creativity is not woman's business. Similarly today such a prominent talent as Edward Radzinsky is capable of openly saying on TV that woman's only purpose and reason for existence is her love for a man [6].

This stance essentially implies that anything beyond kitchen, bedroom and at best living room is not woman's space. On the other hand, interestingly, women themselves by and large agree with the idea that creativity is hardly compatible with motherhood and domestic chores, and, notably, not so much because of the additional demands that the later impose upon a woman, but rather intrinsically. Thus Inna Lisnianskaia wrote "I've ceased to be, I am filling fish with stuffing, I've ceased to be, and so I've called my friends around" (in [12, p. 387]; see also: [12, p. 376] - for the examples of statements that poetry writing is a painful and inappropriate substitute for child-bearing), while neither Tsvetaeva (notoriously) nor Akhmatova (less explicitly) can be regarded as exemplary mothers, having put their craft, at least at some point, above other concerns. By Tsvetaeva's own account life for her would not have any merit if it did not have its literary reflection. This completely overturns man's perception of female creativity, but also reveals a blatant 
gender bias by implicitly pointing an accusing finger at woman for stepping over her primary - i.e. maternal - duties (an accusation which is never applied to a man for putting his work above his paternal duties). Joseph Brodsky was, rather outstandingly, a man who did not seem to share the above male perception with respect to female creativity. Thus he considered Tsvetaeva (a woman) the best poet in history, he claimed that female poetry differs from male poetry by verbal endings only and, remarkably, regarded, in a non-judgmental way, Silvia Plath's suicidal attempts as stemming from her dry spells in poetry rather than from her turbulent love life. Thus, if we trust the sincerity of his statements, not only did he assert her right for creativity, but he placed it above her other concerns, which, if sincere, shows his genuine lack of gender bias with respect to poetry and its authors, despite the reputation of a typical (that is to say, sexist) Russian man that is attributed to him (and maybe rightly so) in certain Western quarters.

The latter observation raises the interesting question of how much we can trust declarations of typical male gender prejudices both in life and in literature, since a lot of feminist interpretations are based on those declarations and their literary reflections. Like David Gillespie's attempt to save derevenskaia proza [village prose] from derevenshchiki [village writers], known for their chauvinistic and reactionary views [10, p. 235], an attempt can be suggested in our case to try and rescue men's literature from its authors' gender-biased rhetoric, and moreover to examine the authenticity of the latter, that is to say its correlation with reality (whether actual or literary). This is particularly relevant in conjunction with Natalia Vinokurova's sociologically-based observations about the discrepancy between men's voices and their actual behaviour with respect to their female partners [15].

The suggestion, which brings us back to the beginning of this essay, is that much of this rhetoric establishing and reaffirming woman's place as in many ways inferior to man's points first of all to men's inner insecurities and constitutes a male attempt at self-assertion and overcoming their inferiority complex, their response to the female sexual threat which in the 1960s and 1970s became also a much broader threat.

A particular example that can be used for this suggested revision is Shmelev's "Pashkov Dom" which, as Svetlana Carsten writes, is an example of "delayed literature written a few years before it could be 
published" [8, p. 260]. This work, which depicts members of the shestidesyatniki generation in the late 1970s, is the focus of a study by Carsten in her article 'In the Shadow of a prominent partner: educated women in literature on the shestidesyatniki'. Carsten complaints that in this work, as in many others, there is no shestidesyatnitsa next to a shestidesyatnik - his female equivalent is simply missing being replaced by an inferior creature that cannot match up his creative and intellectual abilities. Carsten observes that "the preoccupation with the question of women's emancipation typical of the nineteenth century shestidesiatniki" was "lost somewhere is the passage through socialist realism and Soviet existentialism", and now, by contrast with the emancipated women of the 1860s their descendents a century later "sink into complete domesticity" [8, p. 267]. In the story in question Shmelev's protagonist, Gort, is the author's alter ego and a positive hero in the author's eyes. He is from the "new men" of the 1960s, turned "superfluous men" in the 1970s. Gort's life is devoted to scholarly pursuits and his ultimate place is in the library. There are two women in his life: his first love Lelia and his wife Tania. As Carsten points out, "while throughout the novel the author depicts the process of Gort's intellectual evolution and subsequent maturity, his women fail to reach the same intellectual heights and in fact do not achieve much" [8, p. 264]. On the other hand, as Carsten writes about Gort's wife "her function in life as he sees it is to guard and protect his muse from the outside world. There is no feeling of remorse on his part as regards his wife's intellectual, professional, social and spiritual sacrifices. This sacrifice can only be one-sided" [8, p. 268]. So, Gort's wife, as seen by him, is simply a servant to his muse, and her domain of power is restricted to family and home, Carsten explains [8, p. 267].

Now, what kind of a positive hero is this then? we should reasonably ask. This is a man who succeeds essentially at the expense of his wife's sacrifices made to facilitate his artistic fulfillment. Moreover, as Carsten explains, his "relationship with his women serves a very specific purpose - that of nurturing his male vanity, especially his intellect, and assisting in the fulfillment of his ego" [8, p. 268]. Putting it differently, women, with their domestic interests and lack of intellectual concerns, create a favourable background against which Gort's talents stand out more visibly. What is this then, if not a hidden inferiority complex? It is this very complex, Gort's need to reassert his dominance, 
that explains, in my view, an incident when he essentially thwarts his wife's attempts to create a life of her own by successfully acquiring her own circle of friends whom Gort rejects, proving her choice inadequate. Equally, his lover Lelia is depicted as intellectually inferior to him right from the start when instead of engaging, as he did, in advanced scholarship she confines herself to reading fiction. She then betrays him with other men merely out of her desire for material comfort, but he generously forgives her every time. The question thus creeps in: is this not his wounded male ego that attempts to re-establish itself through belittling her intellectual abilities and turning her into a crude materialist rather than searching for reasons for her choice of other men in his own soul and his own behaviour?

As for his wife Tania, her intellectual and creative powers remain simply unexplored. Also, significantly, his choice of the women in his life is conveyed as accidental, rather than conscious, and it is only the path of his scholarly research that was chosen purposefully. This reveals a considerable emotional vacuum in Gort that has not been filled, and sends us back to the nineteenth-century male characters whose condescending, and often cynical attitudes to women stemmed from disillusionment and inner emptiness. After all, rephrasing Brodsky, cynicism is only a form of despair, and literature as much as life itself is filled with despairing characters whose cynicism is an extreme form of defense mechanism, in particular with respect to the opposite sex.

Thus although the author's intentions might have well been to portray Gort as an unambiguously positive hero of profound intellectual merit whose life was stifled by political stagnation and to depict his women as secondary and paltry characters without any creative powers, the text itself suggests a different reading. This suggested angle of vision reverses the seemingly obvious conclusions by leaving the question of Gort's wife's intellectual potential wide open, while Gort's own image becomes dubious rather than impressive. His relationship with his wife is that of an ungrateful son with his devoted mother. Thus the story of Shmelev's Gort is not a tale of intellectual superiority, but of spiritual immaturity.

Speaking more generally, such stories of positive male heroes were predominantly those which, if read carefully, make an opposite impression: of the protagonists being vain, implicitly abusive, 
succeeding at the woman's expense. In the case of a female character, we are often left ignorant as to what her real abilities are, since all her life is essentially a self-sacrifice to facilitate male success and to ensure the survival of the family. And so the women's potential outside the framework of generalised all-pervasive motherhood remains largely unexplored, while many challenges of actual motherhood, in a strict sense of the word, are simply pushed outside literary concerns.

Somewhat different in nature, although equally ambivalent are the conclusions that can be derived from Vasilii Shukshin's story "Drugi igrish i zabav" ["Companions in games and entertainments"] (1975). In it a young woman gives birth to a baby boy, but refuses to reveal to her family (which consists of an older brother and parents) the identity of the father of her child. The brother who (like their father) perceives the whole thing as a total disgrace, sets out to find the sinful man and bring him in to face his fatherly responsibilities, to install him into the family where his place should be from now on. He manages to identify the young man, but misses him and only finds his parents. When he drags his father along to face his grandson, the mother of the baby pretends that this is a case of mistaken identity.

On the one hand, reading this story in a conventional way one can easily interpret it through the usual paradigm of village prose by singling out the corrupting influence of the city which destroys moral foundations and undermines family structures. Also, it displays the patronising role of a male as a protector and leader, and his superior, condescending attitude to a woman whereby the man liberates her even from responsibility for her own actions due to her inferior intellect and a lack of comprehension of reality or absence of will power, or a combination of the above. Thus the brother, who can be regarded as the main protagonist, constantly and desperately repeats that all women are complete fools and hence cannot be held responsible for what they do. He also is a variant of Shukshin's "chudiki": weirdoes, united by an acute sense of dignity and of the absurdity of the world, and in this particular case also marked by an exaggerated sense of justice.

On the other hand, the same story can be re-read in a totally different light. Indeed, the female character (the young mother) is not morally superior to man in a strict sense (along the lines and tradition of 'terrible perfection'), however, morality here is taken outside the 
framework of a narrow understanding of it and the general - or that which is beyond the personal - gives way to the personal. The woman can perhaps evoke pity, but this pity is reversed and redirected by her at the end of the story. Equally, any considerations of materialistic interests and subsequent compromises on her part are out of the question here. In this story the woman in her very motherhood stands above the man, and, in fact, above the world as such. She is depicted ultimately as a repository of dignity and some superior wisdom. Men at the same time find themselves, as it were, at the different sides of the barricades, struck, as if by lightening, by the fact of fatherhood, of the appearance of a new creature, revealing either their triviality or noblesse d'esprit as they see it (for example by fulfilling the function of protector). The theme of male moral inferiority and irresponsibility is overshadowed by the sacred mystery of motherhood. In this perhaps one can trace again a certain idealisation of a woman, but more precisely it is an idealisation of motherhood itself. Also, the same theme - that of women's emancipation in the 1960s and 1970s - is strongly present in this story, where the young mother is a working mother (she works at a post-office), even though she has to abandon her job for a while to nurture the baby. Single motherhood is here implicitly daunting, but is not portrayed as potentially destructive to the well-being of the mother and the child, and even less as a disgrace of any kind. An important point in this connection is the potential support of the woman's extended family which is made clear in the narrative, once this family have resigned themselves to the fact of the baby's birth. Thus the story asserts woman's right to selfdetermination, her ability to choose her own destiny and to insist on it. And the resulting feeling is that both types of men (strong and protective as well as rotten and irresponsible) are left totally defeated by the woman who has transcended to complete independence by her state of motherhood. "She, as soon as she became a mother, immediately got wiser and braver, often played with her baby and laughed" [7, p. 359], the authorial comment reads.

Examples of such double-interpretation where the implicit meaning contradicts the explicit message and shifts gender accents, can be continued.

At the same time equally numerous are examples which illustrate a certain convergence or conformity of men's actions (regardless of their 
anti-feminist rhetoric) with female needs and domestic requirements. Thus in Dragunsky's Deniska's stories the mother gets exasperated, overwhelmed by constant dish-washing, and the conflict is eventually resolved by the father's decision to take part in the process. Similarly in Baranskaia's A Week like any other the husband in fact takes part in domestic chores, even if his share is minimal in comparison to hers. Still, the more standard image of a man to be found in these works is that he is sitting at the table with a newspaper, if not actually lying down on a sofa. This image of a twentieth-century Oblomov permeates the majority of literary works of the late 1960s and 1970s period, reflecting the important process of Soviet men's feminisation. If old gender clichés remained largely intact, this particular archetype was a reflection of a new development both in life and consequently in literature, and its results became particularly evident whenever external conditions were to change rapidly. Thus both in the shock of emigration and the upheavals of perestroika the existential picture was on average the same: men feeling lost, depressed and unable to act, while women pulled themselves together and fought for survival by adjusting to the new conditions and becoming the main breadwinners.

This process of male characters gradually absorbing feminine features in the late 1960s and in the 1970s was indeed a correct reflection of reality. On the one hand, this reality continued the old pattern of ideological pressure undermining human dignity. Dovlatov's hero profoundly suffers from this sense of wounded dignity - as much as the author himself, whose putting up a slogan on the wall on his birthday "35 years in shit and disgrace" (in [1, p. 19]) is a laconic expression of a masculine extreme inner conflict. No less important was the sociological fact of men's inability to make sufficient money by honest means. But there were also new features in this reality that in men's eyes undermined their very masculinity by the increased female dominance, to which they reacted by an increase in specifically anti-female rhetoric which made their vulnerability particularly evident. The most extreme examples of this rhetoric can be found in Mikhail Zhvanetsky's mocking parody of a man's attitude reduced to the cynical formula: "A woman should first lay down, and second - quietly" (Mikhail Zhvanetsky is a celebrated satirical writer who, during the Soviet era, balanced on the edge of what was permissible by the regime and performed his texts on the stage (in 
the style of a Western stand-up comedian)). Or in a common saying: "Women can be of two types: charmingly silly or horribly stupid".

Women's response to this was not feminist in nature. Instead of putting up a fight they essentially recognized once again men's emotional immaturity and, even more importantly, - insecurity. Hence, their reaction was "hot' gorshkom nazyvaj, tol'ko v pech' ne kladi" ["you can call me a pot, as long as you don't actually put me in the oven"], thus essentially dismissing this rhetoric as harmless and defensive, and adopting a familiar mother-son model of relationships between the sexes. Also, interestingly such a stance on men's part emphasised an existing schism between declarations on the one hand and behaviour on the other, which strangely fits into the general Soviet cultural paradigm where thoughts, words and actions were three different things rather than one and the same.

To summarise: the dominant model in the city was that of feminised, weakened men, who would be passed from apron strings to apron strings, thus embodying the image of an eternal son, a perpetual adolescent. Also, the circumstances of political, social and economic restraint (or even slavery) lowered male dignity, thus furthering their inner conflict. The resulting male anti-feminist verbal abuse was met by a condescending and forgiving attitude on women's part, essentially facilitating a mother-son model. However, even if underrepresented in female literature, or conveyed through an indirect mode of discourse the situation was effectively that of female dominance: there was no need to launch a counter-attack, instead women asserted their rights quietly, but surely. Yuri Trifonov's women, for example, are effectively in charge, they make all the strategic decisions, even if this is given a philistine and manipulative slant by the author. In I. Grekova's work women predominantly have no suitable male match, and the impression is that one simply does not exist. In Viktoriia Tokareva's writings female power is all-pervasive, even if implicitly so, while man is often a plaything in a female game.

So, in the persistently sexist pattern emerging from Soviet fiction literature at the time one can see, in what is really a man's pose, the male desire to assert themselves against the encroaching female power, which was now much more than just a sexual threat. 
Thus my conclusion is that the Soviet Union of the 1960s and 1970s at the social and existential level was rapidly turning into an implicitly matriarchal society where all the key roles within a family unit were played by women, and that the tale of family life which is told by Russian Soviet literature is in fact a tale of generalised motherhood, where in the countryside it was old women who were bearers of wisdom and will, while in the urban setting the mother-son model significantly prevailed in relationships between spouses while intrinsically striving to conform to the daughter-father model instead, but essentially failing.

1. Арьев А. Наша маленькая жинь : [предисловие] / Андрей Арьев // Довлатов С. Собрание прозы : в 3 т. - Санкт-Петербург : Лимбус-Пресс, 1993. - T. 1. - C. 5-24.

2. Высоцкий В. Диалог у телевизора / Владимир Высоцкий // Собрание сочинений : в 4 кн. Книга вторая. Мы вращаем землю. - Москва : Надежда-1, 1997. - С. 358-360.

3. Довлатов С. Чемодан / Сергей Довлатов // Собрание прозы : в 3 т. Санкт-Петербург : Лимбус-Пресс, 1993. - Т. 2. - С. 245-340.

4. Нагибин Ю. Предисловие [Надежда Кожевникова. Елена прекрасная. Повесть] / Юрий Нагибин // Новый мир. - 1982. - № 9. - С. 15.

5. Пастернак Б. Доктор Живаго; Автобиографическая проза; Избранные письма / Борис Пастернак. - Москва : Гудьял-пресс, 1998. - 742 с. (Гранд Либрис).

6. Радзинский Э. Театральный роман. ТВ серии, показанные на НТВ, Россия (2004).

7. Шукшин В. Рассказы $=$ Short stories : кн. для чтения с коммент. на англ. яз / В. Шукшин. - Москва : Русский язык, 1984. - 284 с.

8. Carsten $S$. In the Shadow of a Prominent Partner: Educated Women in Literature on the shestidesiatniki / Svetlana Carsten // Women and Russian Culture. Projections and Self-Perceptions / R. Marsh (ed). - New-York; Oxford : Berghahn Books, 1998. - P. 259-274.

9. Curtis J. Iuliia Voznesenskaia: a Fragmentary Vision / Julie Curtis // Women and Russian Culture. Projections and Self-Perceptions / R. Marsh (ed). New-York; Oxford : Berghahn Books, 1998. - P. 173-187.

10. Gillespie D. Is Village Prose Misogynistic? / David Gillespie // Women and Russian Culture. Projections and Self-Perceptions / R. Marsh (ed). - NewYork; Oxford : Berghahn Books, 1998. - P. 234-243.

11. Heldt B. Terrible Perfection. Women and Russian Literature / Barbara Heldt. Bloomington; Indianopolis : Indiana University Press, 1987. - 174 p.

12. Kelly C. A History of Russian Women's Writing 1820-1992 / Catriona Kelly. Oxford : Clarendon Press, 1994. - 497 p. 
13. Lanin B. The Images of Women in the Prose of Sergei Dovlatov / Boris Lanin // Women and Russian Culture. Projections and Self-Perceptions / R. Marsh (ed). - New-York-Oxford : Berghahn Books, 1998. - P. 252-258.

14. Marsh R. Introduction / Rosalind Marsh // Women and Russian Culture. Projections and Self-Perceptions / R. Marsh (ed). - New-York-Oxford : Berghahn Books, 1998. - P. 1-30.

15. Vinokurova N. Re-privatising women's lives: from Khrushchev to Brezhnev / Natalia Vinokurova // Gender, Equality and Difference during and after State Socialism / R. Kay (ed.). - Basingstoke : Palgrave, 2008. - P. 63-84.

\title{
АНТИ-ФЕМИНИСТСКАЯ РИТОРИКА В СОВЕТСКОЙ ЛИТЕРАТУРЕ 60-ЫХ И 70-ЫХ. ПОПЫТКА АЛЬТЕРНАТИВНОЙ ИНТЕРПРЕТАЦИИ
}

\author{
Ольга Табачникова \\ otabachnikova@uclan.ac.uk \\ Доктор философии (кандидат филологических наук), дочент, \\ заведующая кафедрой \\ Кафедра русского языка, литературы и культуры \\ Университет Центрального Ланкашира \\ Ул. Аделфи, PRI 2HE, г. Престон, Великобритания
}

\begin{abstract}
Аннотация. Проводится анализ советской литературы периодов оттепели и застоя (1960-е и 1970-е годы) с гендерной точки зрения и подвергается переоценке существующая (по крайней мере на Западе) парадигма восприятия этой литературы как анти-феминистской. Вначале рассматривается литературное изображение материнства - особенно в случае работающих матерей, - а затем феминистское прочтение этой литературы в более общем случае. Предлагается альтернативная интерпретация литературных произведений данного периода (в особенности написанных мужчинами), подвергающая сомнению их анти-феминистскую направленность. Обнажая скрытые комплексы авторов-мужчин, стоящие за их часто непримиримой реторикой, статья показывает, что доминантой моделью в этой литературе на самом деле служит не патриархальная модель, а как раз модель материнства, но понимаемого в широком смысле. Таким образом эту литературу следует читать как своего рода шифр, поскольку внешне анти-феминистская, она не является таковой по своей сути.

Ключевые слова: гендер, феминизм, анти-феминистская риторика, советская литература, материнство, патриархальный/матриархальный.
\end{abstract}




\title{
RUSSIAN-SOVIET LITERATURE OF THE 1960S AND 1970S: MOTHERHOOD IN DISGUISE, OR A MALE ANTI-FEMINIST RHETHORIC FOR WHAT IT'S WORTH
}

\author{
Olga Tabachnikova \\ otabachnikova@uclan.ac.uk \\ Reader in Russian, Subject Leader for Russian Studies \\ School of Language and Global Studies \\ University of Central Lancashire \\ Adelphi Street, PR1 2HE, Preston, England
}

\begin{abstract}
This paper looks into the Russian Soviet literature of both the "thaw" and "stagnation" periods (1960s and 1970s) in order to reassess the existing paradigm in its critical reception provided from the gender perspective. The discussion starts with consideration of the issue of motherhood - especially in the case of working mothers - and its literary treatment, but then expands to a feminist reading of the literature in question more generally. By suggesting an alternative interpretation of literary works of this period, especially those authored by male writers, the paper challenges the accepted understanding of this literature as essentially misogynistic. By revealing concealed insecurities behind hostile male rhetoric, it turns the tables round to argue that the prevailing model that arises from this literature is, in figurative terms, that of all pervasive motherhood, and as such is actually matriarchal. Thus, the suggestion made, is that this literature should be viewed at least as two-fold: superficially misogynistic, but matriarchal in spirit.

Key words: Gender, feminist/anti-feminist, Soviet literature, motherhood, patriarchal/matriarchal.

\section{References}

1. Ariev, A. Nasha malenkaia zhizn: predislovie [Our little life: introduction:]. In: Dovlatov, S. Sobranie prozy v 3 tomakh. St Petersburg, 1993, vol. 1, pp. 5-24.

2. Vysotsky, V. Dialog u televizora [Dialogue by the TV set]. In: Sobranie sochinenii : v $4 \mathrm{kn}$. Kniga vtoraia. My vrashchaem zemliu. Moscow, 1997, pp. 358-360.

3. Dovlatov, S. Chemodan [Suitcase]. In: Dovlatov, S. Sobranie prozy v 3 tomakh. St Petersburg, 1993, vol. 2, pp. 245-340.

4. Nagibin, Y. Predislovie (Nadezhda Kozhevnikova. Elena prekrasnaia. Povest') [A short preface to Nadezhda Kozhevnikova, "Elena Prekrasnaia"]. Novyi Mir, 1982, no. 9, p. 15.

5. Pasternak, B. Doktor Zhivago; Avtobiograficheskaia proza; Izbrannye pis'ma [Doctor Zhivago; Autobiographical prose; Selected correspondence]. Moscow, 1998, 742 p.
\end{abstract}


6. Radzinsky, E. Teatral'nyi roman [The Theatrical Novel]. A TV series shown by NTV, Russia (2004).

7. Shukshin, V. Rasskazy [Short stories]. Moscow, 1984, 284 p.

8. Carsten, S. In the Shadow of a Prominent Partner: Educated Women in Literature on the shestidesiatniki. In: R. Marsh (ed). Women and Russian Culture. Projections and Self-Perceptions. New-York-Oxford, 1998, pp. 259-274.

9. Curtis, J. Iuliia Voznesenskaia: a Fragmentary Vision. In: R. Marsh (ed). Women and Russian Culture. Projections and Self-Perceptions. New-YorkOxford, 1998, pp. 173-187.

10. Gillespie, D. Is Village Prose Misogynistic? In: R. Marsh (ed). Women and Russian Culture. Projections and Self-Perceptions. New-York-Oxford, 1998, pp. 234-243.

11. Heldt, B. Terrible Perfection. Women and Russian Literature. Bloomington and Indianopolis, 1987, $174 \mathrm{p}$.

12. Kelly, C. A History of Russian Women's Writing 1820-1992. Oxford, 1994, $497 \mathrm{p}$.

13. Lanin, B. The Images of Women in the Prose of Sergei Dovlatov. In: R. Marsh (ed). Women and Russian Culture. Projections and SelfPerceptions. New-York-Oxford, 1998, pp. 252-258.

14. Marsh, R. Introduction. In: R. Marsh (ed). Women and Russian Culture. Projections and Self-Perceptions. New-York-Oxford, 1998, pp. 1-30.

15. Vinokurova, N. Re-privatising women's lives: from Khrushchev to Brezhnev. In: R. Kay (ed.). Gender, Equality and Difference during and after State Socialism. Basingstoke, 2008, pp. 63-84.

\section{Suggested citation}

Tabachnikova O. Russian-Soviet Literature of the 1960s and 1970s: Motherhood in Disguise, or A Male Anti-Feminist Rhethoric for what it's Worth. Pytannia literaturoznavstva, 2017, no. 96, pp. 187-203.

Стаття прийнята до друку 21.11.2017 p. 